
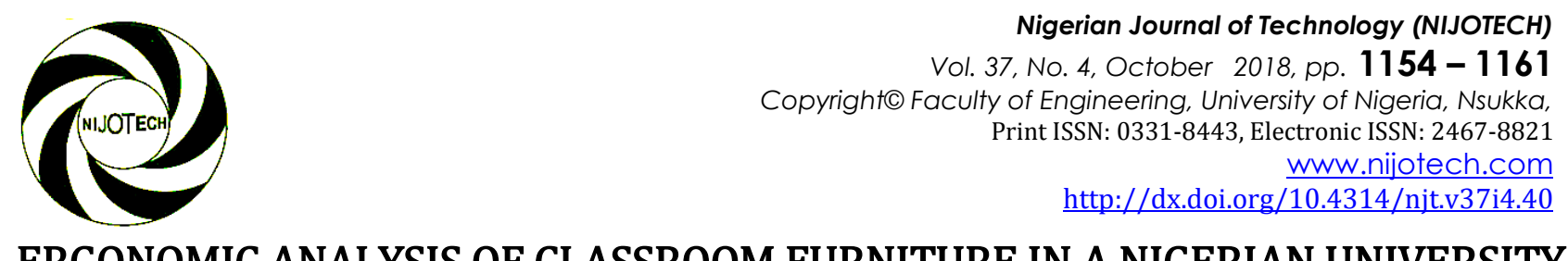

\title{
ERGONOMIC ANALYSIS OF CLASSROOM FURNITURE IN A NIGERIAN UNIVERSITY
}

\author{
O. P. Fidelis ${ }^{1,}$, B. Ogunlade'2, S. A. Adelakun ${ }^{3}$ and O. Adukwu ${ }^{4}$

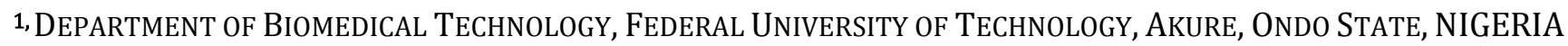

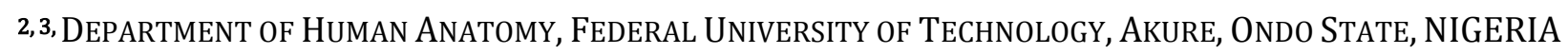 \\ 4, DePt. of Industrial \& Production Engr., Federal Univ. of TeChNology, AKURE, ONdo STATE, NigERIA. \\ E-mail addresses: ${ }^{1}$ opfidelis@futa.edu.ng; ${ }^{2}$ bogunlade@futa.edu.ng; ${ }^{3}$ saadelakun@futa.edu.ng \\ 4oadukwu@futa.edu.ng
}

\begin{abstract}
In most underdeveloped and developing countries, the anthropometric dimensions of users are not deployed in classroom furniture design. This has severe health as well as learning implications. The aim of this study was to determine the ergonomic suitability of classroom furniture at the Federal University of Technology, Akure, Nigeria. 261 (133 males and 128 females) randomly selected students participated in the study. Their anthropometric measures were taken after fully explaining the purpose and procedure of the measurements and obtaining an informed consent from each student. The dimensions of the furniture in all the selected lecture venues were also taken. The level of match/mismatch between the anthropometric measures of the students and classroom furniture was afterwards determined using some criterion equations. The result of the study showed a substantial level of mismatch between the anthropometric measures of students and the dimensions of the furniture available to them for use in lecture venues. In all, $31.8 \%$ and $37.2 \%$ of the participants in the study used seats that are too high and too low respectively for their anthropometric measures while $18.4 \%$ and $50.6 \%$ of the participants used seats that are too deep and too shallow respectively for their anthropometric measures. The study revealed that $90 \%$ of all the participants used desks that were too high, $2 \%$ used desks that were too low and only $7 \%$ used desks with heights that fit their anthropometric measures. Only at one lecture venue was a non-zero score (5.5\%) returned for a combined seat height - seat depth analysis. The study evidently suggests that many students use unfit classroom furniture which are not conducive for learning.
\end{abstract}

Keywords: anthropometric measures; ergonomics; furniture mismatch; Nigeria

\section{INTRODUCTION}

The use of ill-fitted furniture presents a risk of suffering negative effects by users [1]. These effects may however be prevented by adopting correct sitting postures [2] on well-designed seats [3]. The problems arise, in the first place because, in most underdeveloped and developing countries, classroom furniture is often poorly designed and unfit for learning [4]. The nature of activities performed in a classroom, the anthropometric data of the student, the design of the classroom furniture $[5,6]$ as well as the individual's postural habits [7], all influence the sitting posture of a student.

It has become important that classroom furniture be designed to suit the end users [8]. This is applicable to the University environment as well, because repetitive strain injuries which may occur from poor sitting postures not only affect primary school children and teenagers but are also evident in college students [9]. The anthropometric dimensions necessary for designing very good furniture which will promote correct sitting posture and reduce the incidence of musculoskeletal disorders include popliteal height, buttock-popliteal length, knee height, elbow-seat height, shoulder height, hip width, thigh thickness [1, 913].

Mismatch between students' anthropometric dimensions and furniture dimensions can affect classroom activities such as writing, reading and typing; causing pain in the back, shoulders, neck, legs and eye [1, 14-16]. Mismatches between the human anthropometric measures and equipment, tools and furniture, also has the tendency of resulting in decline 
in productivity, discomfort, accidents, biomechanical stress, fatigue, injuries, and cumulative traumas [17].

Ergonomic designs which suit users and reduce discomfort resulting from use rely on a number of tools one of which is the anthropometric measurements of the end-user [12]. Sadly, there is a dearth of information on the ergonomic suitability of educational furniture for students, especially in the higher institutions of learning in Nigeria [13] and more studies should be conducted to fill the void. Mokdad and AlAnsari [12] observed that anthropometric studies where available in developing countries (like Nigeria) are old and may not be reliable due to secular changes in those societies resulting from improved nutritional and health programs, as well as social and security practices. Whether school furniture is locally designed or imported, the consideration of users' anthropometric data in such designs is germane to reducing discomfort and musculoskeletal disorders that may arise from the use of such furniture.

The design of classroom furniture for Nigerian schools with anthropometric measurements obtained from other parts of the world is unacceptable because body composition, size and shape have been reported to differ across races and nations [18]. Therefore, the aim of this study is to obtain anthropometric data of students of the University, compare the anthropometric dimensions of the students with the dimensions of the furniture present in the different lecture venues and to determine the level of match/mismatch.

\section{MATERIALS AND METHOD}

\subsection{Participants}

The study participants were students of the Federal University of Technology, Akure, Nigeria, who attended lectures at the selected lecture venues.

\subsection{Inclusion criteria}

Only students who had their lectures at the selected venues and gave informed consents were included in this study.

\subsection{Instruments}

The measurements were taken using the traditional anthropometric tools like most previous researchers $[9-13,16,17,19]$. Anthropometric dimensions were measured with a portable anthropometer with the exception of the standing height (stature) which was measured with a stadiometer. The classroom furniture dimensions were taken using a metal tape.

\subsection{Sample Size and Sampling Technique}

Six (6) lecture venues were selected for this study. The choice of the selected venues was based on the differences in the design of the furniture in these venues. In addition, these venues represent the most popular and heavily used lecture venues on campus.

A total of two hundred and six-one (261) students participated in the study. The population size was determined using the number of seats in the largest lecture hall and a sample of convenience was used to select participants [13]. The sample size for each lecture theatre was obtained from equation 1 as presented in $[1,13,19]$.

$$
n=N /\left(1+N\left[e^{2}\right]\right)
$$

where $\mathrm{n}$ is the sample size to be determined, $\mathrm{N}$ is the population size, e is the level of precision.

The largest of the lecture theatres selected for this study (Education Trust Fund, ETF, lecture theatre) has a sitting capacity of 700 . The level of precision is $\pm 5 \%$. Therefore, applying equation 1 , the sample size was obtained as 261 students. The sample size proportion from each lecture theatre was then calculated as:

$$
\begin{aligned}
& \text { Sample Size Proportion } \\
& =\frac{\text { Capacity of lecture theatre X Sample size }}{\text { Total capacity of lecture theatres }}
\end{aligned}
$$

\subsection{Data collection}

A total of 261 students (133 males and 128 females) were selected from the six lecture venues. The purpose of the study was clearly explained to the participants and an informed consent was obtained from each participating student. They were all told to present themselves for the measurements in light clothing.

The anthropometric dimensions of the students were taken from the right side of each person, while they were sitting in an erect position on a height-adjustable chair with a horizontal surface and had no shoes on them. The knees and elbow were flexed at $90^{\circ}$. A survey team was assembled for this study and trained in a special pilot study.

\subsection{Anthropometric Dimensions}

The following anthropometric dimensions, as defined by ISO 7250, 1996, and reported in previous studies $[19,20]$ were considered and collected during the study.

- Stature (body height): the vertical distance from the floor to highest point of the head (vertex).

- Shoulder height (sitting): the vertical distance from the horizontal sitting surface to the acronium. 
- Elbow height (sitting): the vertical distance from a horizontal sitting surface to the lowest bony projection of the elbow bent at a right angle with the forearm horizontal.

- Popliteal height: vertical distance from the floor to the popliteal angle at the underside of the knee where the tendon of the biceps femoris muscle inserts into the lower leg.

- Buttock-popliteal length: horizontal distance from the back of the uncompressed buttocks to the popliteal angle, at the back of the knee, where the back of the lower legs meet the underside of the thigh.

- Knee height: vertical distance from the floor to the upper surface of the knee (usually measured to the quadriceps muscle rather than the kneecap).

- Thigh thickness (thigh clearance): the vertical distance from the sitting surface to the highest point on the thigh.

- Hip width: horizontal distance of the body measured across the widest portions of the hips.

\subsection{Furniture Dimension}

The following furniture dimensions were taken as well. The definitions are as presented in previous studies [9], [13], [16], [20].

- Seat height: the distance from the floor to the highest point on the front of the seat.

- Seat depth: the distance from the back of the seating surface of the seat to its front.

- Seat width: the horizontal distance across the sides of the seating surface.

- Back rest height: the vertical surface from the seating surface of the seat to the top edge of the back rest.

- Desk height: the vertical distance from the floor to the top of the front edge of the desk.

- Under desk height: the vertical distance from the floor to the bottom of the front edge of the desk.

- Seat-desk height: the vertical distance from the seating surface of the seat to the top of the front edge of the desk.

- Desk angle: the angle of slope of the writing surface of the desk.

\subsection{Applications of the Measures and Criterion Equations}

Anthropometric match (or mismatch) describes a condition of fit (or unfit) between the anthropometric measure of a person and furniture dimensions and is determined using equations obtained from previous studies such as [1, 10-11, 13, 19]. Previous studies suggest that the popliteal height is expected to be higher than the height of the seat $[1,10,21]$. According to Odunaiya, Owonuwa and Oguntibeju [13], a seat height $>95 \%$ or $<88 \%$ of the popliteal height represents a mismatch. Therefore the match criterion can be obtained from equation 3 adapted from similar studies $[10,16]$.

$(P H+3) \cos 30^{\circ} \leq S H \leq(P H+3) \cos 5^{\circ}$

Where: 3 represents the shoe correction factor of $3 \mathrm{~cm}$ in the equation above.

$\mathrm{PH}$ represents popliteal height (in centimetres) and $\mathrm{SH}$ represents seat height (in centimetres). The angles $5^{\circ}$ and $30^{\circ}$ represents the range of angles necessary to permit a user to sit on a chair which is high enough so that both feet are well supported on the floor and prevent a slumped, kyphotic posture [1] and low enough to avoid an extension of more than $30^{\circ}$ relative to the vertical in the knee joint [11].

Also, Castellucci, Arevez and Viviani [10] proposed that the seat depth should be designated for the fifth percentile of Buttock-popliteal length. The match criterion is presented by equation 4 , adapted from [1]. $80 \% B P L \leq S D \leq 95 \% B P L$

BPL is the buttock-popliteal length (in centimetres); and SD is the seat depth (in centimetres)

The seat width should be large enough to accommodate the largest hip width [21] and is therefore designated for the $95^{\text {th }}$ percentile of hip width [10], [19]. The match criterion was adapted from [10] and presented in equation 5 .

$$
H W<S W
$$

HW is the hip width (in centimetres); and SW is the seat width (in centimetres)

The thigh clearance is used to determine (and is therefore related to) the seat-desk clearance. It is an indication of how much space should exist between the seat and the bottom edge of the desk. Parcells et al [1] recommends a seat-desk clearance which is $2 \mathrm{~cm}$ higher than the thigh clearance. The match criterion for thigh clearance is therefore presented in equation (6).

$$
T T+2 \leq S D C
$$

TT is the thigh thickness (in centimetres); and SDC is the seat-desk clearance (in centimetres)

The elbow height is used to determine appropriate seat-desk height because when arms can be supported on the desk surface, there is a reduction in the load on the spine [21]. Based on the recommendation that the desk height should be $3-5 \mathrm{~cm}$ higher than the elbow height, and that the maximum seat-desk height should not be more than $5 \mathrm{~cm}$ higher than the elbow height, the match criterion for elbow height and seat-desk height is adapted from [10], [11] as follows:

Vol. 37, No. 4, October, 2018 


$$
E H \leq S D H \leq E H+5
$$

$\mathrm{EH}$ is the elbow height (in centimetres); $\mathrm{SDH}$ is the seat-desk height (in centimetres)

Finally, back rest is considered appropriate when it is below the scapula. The criterion equation adapted from [16] suggests that the back rest height be at most $60 \%$ $80 \%$ of shoulder height and is presented below;

$$
0.6 S H \leq B H \leq 0.8 S H
$$

$\mathrm{SH}$ is the shoulder height (centimetres); and $\mathrm{BH}$ is the backrest height (centimetres).

\section{RESULTS}

The dimensions of the furniture in the venues are shown in Table 1. A minimum of two different measurements were taken for each furniture dimension and the average measurement was recorded.

At 3-In-1, ETF, LT 1 and LT 2, the seats and desks are wooden and bench-like. The seats in LT 1 have wooden sitting surface and cushioned backrest. At LT 2, both sitting surfaces and backrests are cushioned. ETF, FBN and 3-In-1 have neither cushioned sitting surfaces nor cushioned backrests. The furniture in these venues is arranged in horizontal, elevated orientation, from the front to the rear except for 3-In-1 with a level floor orientation. FBN has wooden, retractable seats and wooden bench-like desk. The seats are arranged in horizontal elevated orientation. The furniture in the NEEDS assessment classrooms are made of plastic and retractable with a right-sided writing platform.

The results obtained from the analysis of students' anthropometric dimensions as obtained from the various lecture venues are shown in Table 2 . The data is described in terms of the minimum, maximum, median and mean \pm standard deviation values for male and female participants. The anthropometric data of the study participants was collated, computed and analysed using Microsoft Excel (version 2010) and Statistical Package for Social Sciences (SPSS) version 21.

Table 1: showing furniture dimensions at the selected lecture venues in FUTA

\begin{tabular}{lcccccc}
\hline & $\begin{array}{c}\text { 3-In-1 Lecture } \\
\text { theatre } \\
(\mathrm{N}=300)\end{array}$ & $\begin{array}{c}\text { ETF Lecture } \\
\text { theatre }(\mathrm{N}= \\
700)\end{array}$ & $\begin{array}{c}\text { FBN Lecture } \\
\text { theatre } \\
(\mathrm{N}=500)\end{array}$ & $\begin{array}{c}\text { Lecture } \\
\text { theatre 1 } \\
(\mathrm{N}=500)\end{array}$ & $\begin{array}{c}\text { Lecture } \\
\text { theatre 2 } \\
(\mathrm{N}=300)\end{array}$ & $\begin{array}{c}\text { NEEDS Assessment } \\
\text { Lecture Rooms } \\
(\mathrm{N}=120)\end{array}$ \\
\hline $\begin{array}{l}\text { Seat height } \\
\text { Seat depth }\end{array}$ & 46.40 & 36.70 & 43.50 & 47.50 & 49.00 & 37.00 \\
$\begin{array}{l}\text { Seat width } \\
\begin{array}{l}\text { Backrest } \\
\text { height }\end{array}\end{array}$ & 43.30 & 41.20 & 46.30 & 28.50 & 32.00 & 36.50 \\
$\begin{array}{l}\text { Seat-desk } \\
\text { height }\end{array}$ & 33.50 & 43.60 & 41.00 & 43.00 & 46.50 & 44.50 \\
$\begin{array}{l}\text { Seat-desk } \\
\text { clearance }\end{array}$ & 29.40 & 56.60 & 46.50 & 58.50 & 55.00 & 42.00 \\
\hline
\end{tabular}

$N=$ sitting capacity of the lecture venue;

All dimensions are in centimetres (cm)

\begin{tabular}{|c|c|c|c|c|c|c|c|c|c|}
\hline \multirow{2}{*}{ Lecture Venue } & \multirow{2}{*}{$\begin{array}{l}\text { Anthropometric } \\
\text { Measure }\end{array}$} & \multicolumn{4}{|c|}{ Male } & \multicolumn{4}{|c|}{ Female } \\
\hline & & Min & $\operatorname{Max}$ & Median & $M e a n \pm S D$ & Min & $\operatorname{Max}$ & Median & $\operatorname{Mean} \pm S D$ \\
\hline \multirow{7}{*}{$\begin{array}{l}\text { 3-In-1 Lecture } \\
\text { Theatre }(n=34)\end{array}$} & Stature & 146.0 & 190.0 & 173.0 & $172.3 \pm 9.6$ & 150.0 & 173.0 & 164.0 & $162.9 \pm 7.7$ \\
\hline & Popliteal height & 38.0 & 49.0 & 44.5 & $44.4 \pm 2.5$ & 39.0 & 44.0 & 42.0 & $42.0 \pm 1.7$ \\
\hline & $\begin{array}{l}\text { Buttock-Popliteal } \\
\text { length }\end{array}$ & 43.7 & 57.5 & 48.5 & $49.1 \pm 3.7$ & 41.5 & 51.3 & 45.3 & $46.2 \pm 3.1$ \\
\hline & Elbow height & 12.0 & 25.0 & 20.0 & $19.6 \pm 3.2$ & 12.5 & 24.5 & 17.5 & $17.9 \pm 3.2$ \\
\hline & Hip width & 23.0 & 34.7 & 30.0 & $29.6 \pm 2.9$ & 28.5 & 36.0 & 34.0 & $33.0 \pm 2.4$ \\
\hline & Thigh thickness & 12.0 & 18.0 & 13.0 & $13.6 \pm 1.6$ & 10.5 & 14.0 & 13.0 & $12.5 \pm 1.0$ \\
\hline & Shoulder height & 46.7 & 62.0 & 56.5 & $55.8 \pm 4.5$ & 49.0 & 60.0 & 52.0 & $53.2 \pm 3.7$ \\
\hline \multirow{6}{*}{$\begin{array}{l}\text { ETF Lecture } \\
\text { Theatre }(n=76)\end{array}$} & Stature & 161.0 & 187.0 & 170.0 & $171.9 \pm 6.6$ & 148.0 & 173.0 & 164.0 & $162.7 \pm 5.8$ \\
\hline & Popliteal height & 41.0 & 52.0 & 45.2 & $46.0 \pm 2.8$ & 39.5 & 47.5 & 43.5 & $43.5 \pm 2.1$ \\
\hline & $\begin{array}{l}\text { Buttock-Popliteal } \\
\text { length }\end{array}$ & 41.2 & 55.0 & 48.0 & $48.1 \pm 3.3$ & 40.0 & 53.0 & 47.5 & $47.0 \pm 2.9$ \\
\hline & Elbow height & 12.0 & 25.0 & 16.4 & $16.4 \pm 2.9$ & 12.8 & 30.0 & 16.0 & $16.5 \pm 3.0$ \\
\hline & Hip width & 27.0 & 38.0 & 31.0 & $31.6 \pm 2.5$ & 28.0 & 43.5 & 33.5 & $33.7 \pm 4.0$ \\
\hline & Thigh thickness & 9.5 & 18.0 & 14.0 & $13.8 \pm 1.9$ & 10.0 & 19.0 & 13.0 & $13.6 \pm 2.0$ \\
\hline
\end{tabular}

Table 2: showing the anthropometric measures of students selected from various lecture venues in FUTA 


\begin{tabular}{|c|c|c|c|c|c|c|c|c|c|}
\hline \multirow{3}{*}{ Lecture Venue } & \multirow{2}{*}{$\begin{array}{l}\text { Anthropometric } \\
\text { Measure }\end{array}$} & \multicolumn{4}{|c|}{ Male } & \multicolumn{4}{|c|}{ Female } \\
\hline & & Min & $\operatorname{Max}$ & Median & $M e a n \pm S D$ & Min & $\operatorname{Max}$ & Median & $M e a n \pm S D$ \\
\hline & Shoulder height & 46.0 & 62.0 & 55.8 & $55.0 \pm 3.9$ & 47.0 & 60.0 & 51.8 & $51.9 \pm 2.8$ \\
\hline \multirow{7}{*}{$\begin{array}{l}\text { FBN Lecture } \\
\text { Theatre }(n=54)\end{array}$} & Stature & 160.0 & 188.0 & 172.0 & $172.3 \pm 6.9$ & 156.0 & 174.0 & 163.0 & $162.7 \pm 3.9$ \\
\hline & Popliteal height & 40.2 & 52.0 & 45.0 & $45.1 \pm 2.8$ & 40.0 & 48.0 & 43.0 & $42.9 \pm 2.5$ \\
\hline & $\begin{array}{l}\text { Buttock-Popliteal } \\
\text { length }\end{array}$ & 42.0 & 54.5 & 48.0 & $48.0 \pm 3.0$ & 40.0 & 51.5 & 46.0 & $45.7 \pm 2.5$ \\
\hline & Elbow height & 11.4 & 24.5 & 18.0 & $18.2 \pm 3.6$ & 11.0 & 30.0 & 17.5 & $18.6 \pm 5.2$ \\
\hline & Hip width & 28.0 & 38.0 & 30.0 & $31.3 \pm 2.5$ & 28.0 & 43.0 & 34.0 & $34.5 \pm 4.2$ \\
\hline & Thigh thickness & 9.5 & 17.0 & 13.0 & $13.0 \pm 1.7$ & 10.0 & 18.0 & 12.0 & $12.5 \pm 2.1$ \\
\hline & Shoulder height & 51.0 & 63.0 & 56.5 & $56.9 \pm 3.1$ & 44.0 & 60.0 & 52.3 & $52.5 \pm 3.8$ \\
\hline \multirow{7}{*}{$\begin{array}{l}\text { Lecture Theatre } \\
1(n=54)\end{array}$} & Stature & 159.0 & 189.0 & 173.0 & $173.2 \pm 7.7$ & 152.0 & 172.0 & 161.5 & $161.0 \pm 4.8$ \\
\hline & Popliteal height & 40.2 & 51.0 & 45.0 & $44.9 \pm 2.8$ & 39.0 & 50.0 & 42.0 & $42.7 \pm 2.8$ \\
\hline & $\begin{array}{l}\text { Buttock-Popliteal } \\
\text { length }\end{array}$ & 45.0 & 56.0 & 48.0 & $49.2 \pm 3.0$ & 41.0 & 51.5 & 45.8 & $45.9 \pm 2.5$ \\
\hline & Elbow height & 12.0 & 25.0 & 18.5 & $19.2 \pm 3.4$ & 13.0 & 25.0 & 16.3 & $16.6 \pm 2.7$ \\
\hline & Hip width & 22.0 & 35.0 & 30.5 & $30.3 \pm 2.6$ & 28.0 & 41.0 & 33.5 & $33.5 \pm 3.2$ \\
\hline & Thigh thickness & 9.5 & 17.0 & 14.0 & $13.7 \pm 1.7$ & 10.0 & 16.0 & 12.5 & $12.7 \pm 1.8$ \\
\hline & Shoulder height & 46.0 & 62.0 & 57.0 & $56.4 \pm 4.0$ & 48.0 & 59.0 & 52.0 & $52.0 \pm 3.0$ \\
\hline \multirow{7}{*}{$\begin{array}{l}\text { Lecture Theatre } \\
2(n=32)\end{array}$} & Stature & 157.0 & 186.0 & 171.0 & $171.1 \pm 6.9$ & 157.0 & 173.0 & 161.5 & $161.7 \pm 5.0$ \\
\hline & Popliteal height & 40.0 & 55.0 & 43.2 & $43.8 \pm 3.2$ & 38.5 & 47.0 & 41.8 & $42.3 \pm 2.8$ \\
\hline & $\begin{array}{l}\text { Buttock-Popliteal } \\
\text { length }\end{array}$ & 41.5 & 59.0 & 48.0 & $48.3 \pm 3.4$ & 42.5 & 51.0 & 47.0 & $46.6 \pm 2.4$ \\
\hline & Elbow height & 13.0 & 25.0 & 17.0 & $17.5 \pm 3.0$ & 16.0 & 28.0 & 22.0 & $22.4 \pm 3.5$ \\
\hline & Hip width & 27.0 & 38.0 & 30.3 & $30.7 \pm 2.9$ & 23.0 & 42.0 & 35.5 & $34.3 \pm 5.8$ \\
\hline & Thigh thickness & 10.0 & 14.0 & 10.8 & $11.5 \pm 1.6$ & 8.5 & 15.0 & 12.0 & $12.1 \pm 1.9$ \\
\hline & Shoulder height & 44.0 & 61.0 & 54.8 & $54.9 \pm 3.7$ & 51.0 & 58.0 & 53.5 & $53.5 \pm 2.2$ \\
\hline \multirow{7}{*}{$\begin{array}{l}\text { NEEDS } \\
\text { Assessment } \\
\text { Lecture Room } \\
(n=13)\end{array}$} & Stature & 168.0 & 182.0 & 172.5 & $173.9 \pm 5.2$ & 158.0 & 165.0 & 165.0 & $164.1 \pm 4.3$ \\
\hline & Popliteal height & 41.4 & 48.0 & 45.3 & $45.0 \pm 2.2$ & 41.5 & 46.0 & 45.0 & $44.1 \pm 1.8$ \\
\hline & $\begin{array}{l}\text { Buttock-Popliteal } \\
\text { length }\end{array}$ & 44.5 & 53.5 & 48.3 & $49.2 \pm 3.3$ & 45.0 & 48.0 & 45.6 & $46.0 \pm 1.0$ \\
\hline & Elbow height & 15.0 & 21.0 & 20.0 & $19.4 \pm 2.2$ & 14.0 & 19.2 & 17.5 & $16.5 \pm 2.3$ \\
\hline & Hip width & 27.0 & 33.0 & 30.0 & $29.7 \pm 2.1$ & 30.5 & 38.0 & 36.0 & $34.4 \pm 3.1$ \\
\hline & Thigh thickness & 14.0 & 17.0 & 15.0 & $15.3 \pm 1.1$ & 10.5 & 16.0 & 12.5 & $13.1 \pm 2.5$ \\
\hline & Shoulder height & 55.0 & 60.5 & 57.0 & $57.2 \pm 1.7$ & 48.0 & 54.5 & 51.0 & $51.4 \pm 2.5$ \\
\hline
\end{tabular}

$n=$ sample size; Min = minimum; Max = maximum; $S D=$ standard deviation; All dimensions are in centimetres (cm)

Two kinds of equations have been used in the present study; the two-way equations (equations 3, 4, 7 and 8) and the one-way equations (equations 5 and 6). The two way equations can be interpreted as match, low mismatch and high mismatch. A "match" exists when the furniture dimension is between the lower and upper limits of the criterion equation; a "high mismatch" is when the upper limit of the criterion equation is lower than the furniture dimension under consideration and a "low mismatch" exists when the lower limit of the criterion equation is higher than the furniture dimension under consideration. The levels of match/mismatch are shown in Table 3.

The results obtained for 3-In-1 lecture classroom showed that the seat height matched for $56 \%$ of the participants in the study. $44 \%$ recorded a highmismatch. This means that $44 \%$ of the participants from that lecture classroom are using seats that are too high for their anthropometric dimension. In addition, $96.9 \%$ of the participants were using seats that are too shallow for their measures. $44 \%$ returned a high mismatch for backrest height and $100 \%$ low mismatch for seat-desk height. 
Table 3: showing levels of match/mismatch of furniture dimensions with anthropometric dimensions of students at the selected lecture venues in FUTA

\begin{tabular}{|c|c|c|c|c|c|c|}
\hline & $\begin{array}{l}3 \text {-In-1 } \\
\text { Lecture } \\
\text { theatre } \\
(n=300)\end{array}$ & $\begin{array}{l}\text { ETF Lecture } \\
\text { theatre }(n= \\
700)\end{array}$ & $\begin{array}{l}\text { FBN Lecture } \\
\text { theatre } \\
(n=500)\end{array}$ & $\begin{array}{l}\text { Lecture } \\
\text { theatre } 1 \\
(n=500)\end{array}$ & $\begin{array}{l}\text { Lecture theatre } \\
2(n=300)\end{array}$ & $\begin{array}{l}\text { NEEDS } \\
\text { Assessment } \\
\text { Lecture Rooms } \\
(\mathrm{n}=120)\end{array}$ \\
\hline $\begin{array}{l}\text { Seat } \\
\text { height }\end{array}$ & $\begin{array}{l}\text { (56\% match; } \\
44 \% \text { high } \\
\text { mismatch) }\end{array}$ & $\begin{array}{l}\text { (3\% match; } \\
97 \% \text { low } \\
\text { mismatch) }\end{array}$ & $\begin{array}{l}\text { (75.9\% match; } \\
13 \% \text { high } \\
\text { mismatch; } \\
11.1 \% \text { low } \\
\text { mismatch) }\end{array}$ & $\begin{array}{l}(44.4 \% \\
\text { match; } \\
65.6 \% \text { high } \\
\text { mismatch })\end{array}$ & $\begin{array}{l}\text { (12.5\% match; } \\
84.4 \% \text { high } \\
\text { mismatch; } \\
3.1 \% \text { low } \\
\text { mismatch }\end{array}$ & $\begin{array}{l}\text { (100\% low } \\
\text { mismatch) }\end{array}$ \\
\hline Seat depth & $\begin{array}{l}\text { (3.1\% match; } \\
96.9 \% \text { low } \\
\text { mismatch) }\end{array}$ & $\begin{array}{l}\text { (82.9\% match; } \\
7.9 \% \text { high } \\
\text { mismatch; } \\
9.2 \% \text { low } \\
\text { mismatch) }\end{array}$ & $\begin{array}{l}\text { (22\% match; } \\
78 \% \text { low } \\
\text { mismatch) }\end{array}$ & $\begin{array}{l}\text { (100\% high } \\
\text { mismatch) }\end{array}$ & $\begin{array}{l}\text { (100\% high } \\
\text { mismatch) }\end{array}$ & $\begin{array}{l}\text { (38.5\% match; } \\
61.5 \% \text { low } \\
\text { mismatch) }\end{array}$ \\
\hline Seat width & $\begin{array}{l}(100 \% \\
\text { match })\end{array}$ & (100\% match) & $\begin{array}{l}\text { (98\% match; } \\
2 \% \text { mismatch) }\end{array}$ & $\begin{array}{l}(100 \% \\
\text { match })\end{array}$ & (100\% match) & (100\% match) \\
\hline $\begin{array}{l}\text { Backrest } \\
\text { height }\end{array}$ & $\begin{array}{l}\text { (56\% match; } \\
44 \% \text { low } \\
\text { mismatch) }\end{array}$ & $\begin{array}{l}\text { (100\% high } \\
\text { mismatch) }\end{array}$ & $\begin{array}{l}\text { (20.4\% match; } \\
79.6 \% \text { high } \\
\text { mismatch) }\end{array}$ & $\begin{array}{l}\text { (100\% high } \\
\text { mismatch) }\end{array}$ & $\begin{array}{l}\text { (100\% high } \\
\text { mismatch) }\end{array}$ & $\begin{array}{l}(69.2 \% \text { match; } \\
30 \% \text { high } \\
\text { mismatch) }\end{array}$ \\
\hline $\begin{array}{l}\text { Seat-desk } \\
\text { height }\end{array}$ & $\begin{array}{l}\text { (100\% high } \\
\text { mismatch) }\end{array}$ & $\begin{array}{l}\text { (5.2\% match; } \\
94.8 \% \text { high } \\
\text { mismatch) }\end{array}$ & $\begin{array}{l}\text { (100\% high } \\
\text { mismatch) }\end{array}$ & $\begin{array}{l}\text { (3.7\% match; } \\
96.3 \% \text { high } \\
\text { mismatch) }\end{array}$ & $\begin{array}{l}\text { (40.6\% match; } \\
43.8 \text { high } \\
\text { mismatch; } \\
15.6 \% \text { low } \\
\text { mismatch) }\end{array}$ & $\begin{array}{l}\text { (100\% high } \\
\text { mismatch) }\end{array}$ \\
\hline $\begin{array}{l}\text { Seat-desk } \\
\text { clearance }\end{array}$ & $\begin{array}{l}(100 \% \\
\text { match) }\end{array}$ & (100\% match) & (100\% match) & $\begin{array}{l}(100 \% \\
\text { match })\end{array}$ & (100\% match) & $(100 \%$ match $)$ \\
\hline
\end{tabular}

$n=$ sitting capacity of the lecture venue

At ETF, 97\% returned a low mismatch for seat height. This means that $97 \%$ of sampled population were using seats too low for their anthropometric measures. However, the seat depth suits $82.9 \%$ with a $94.8 \%$ high mismatch for seat-desk height. The seat height for furniture at FBN lecture theatre fits $75.9 \%$ of the participants but with a 78\% high mismatch for seat depth and $79.6 \%$ high mismatch for backrest height. At LT 1, a $65.6 \%$ high mismatch was returned for the seat height. The seat was too shallow for $100 \%$ of the participants and the desk was too high for $96.3 \%$ of the participants. LT 2 and NEEDS assessment classroom returned $84.4 \%$ high mismatch and 100\% low mismatch respectively for seat height and $100 \%$ low mismatch and $61.5 \%$ low mismatch respectively for the seat depth.

A combined match/mismatch of seat height and seat depth for each lecture venue was also determined. The results are shown in Table 4 - Table 9.

At the 3-In-1 lecture room, it was found that neither the seat height nor seat depth matched the anthropometric dimensions of the users in $43.75 \%$ of the cases. In other words, $43.75 \%$ of the students population were using a seat either too high and/or too low and also either too deep and/or too shallow.
Table 4: showing combined seat height and seat depth match/mismatch levels for 3-In-1.

\begin{tabular}{ccc}
\hline \multirow{2}{*}{ Seat depth } & \multicolumn{2}{c}{ Seat height } \\
\cline { 2 - 3 } & Match & Mismatch \\
\hline Match & $0 \%$ & $3.1 \%$ \\
Mismatch & $56.25 \%$ & $43.75 \%$ \\
\hline
\end{tabular}

Table 5: showing combined seat height and seat depth match/mismatch levels for LT 2 .

\begin{tabular}{ccc}
\hline \multirow{2}{*}{ Seat depth } & \multicolumn{2}{c}{ Seat height } \\
\cline { 2 - 3 } & Match & Mismatch \\
\hline Match & $0 \%$ & $0 \%$ \\
Mismatch & $15.6 \%$ & $84.4 \%$ \\
\hline
\end{tabular}

Table 6: showing combined seat height and seat depth match/mismatch levels for NEEDS.

\begin{tabular}{ccc}
\hline \multirow{2}{*}{ Seat depth } & \multicolumn{2}{c}{ Seat height } \\
\cline { 2 - 3 } & Match & Mismatch \\
\hline Match & $0 \%$ & $38.5 \%$ \\
Mismatch & $0 \%$ & $61.5 \%$ \\
\hline
\end{tabular}

Table 7: showing combined seat height and seat depth match/mismatch levels for FBN.

\begin{tabular}{ccc}
\hline \multirow{2}{*}{ Seat depth } & \multicolumn{2}{c}{ Seat height } \\
\cline { 2 - 3 } & Match & Mismatch \\
\hline Match & $5.5 \%$ & $13 \%$ \\
Mismatch & $72.2 \%$ & $13 \%$ \\
\hline
\end{tabular}


Table 8: showing combined seat height and seat depth match/mismatch levels for LT 1 .

\begin{tabular}{ccc}
\hline \multirow{2}{*}{ Seat depth } & \multicolumn{2}{c}{ Seat height } \\
\cline { 2 - 3 } & Match & Mismatch \\
\hline Match & $0 \%$ & $0 \%$ \\
Mismatch & $40.7 \%$ & $59.3 \%$ \\
\hline
\end{tabular}

Table 9: showing combined seat height and seat depth match/mismatch levels for ETF.

\begin{tabular}{ccc}
\hline \multirow{2}{*}{ Seat depth } & \multicolumn{2}{c}{ Seat height } \\
\cline { 2 - 3 } & Match & Mismatch \\
\hline Match & $0 \%$ & $82.9 \%$ \\
Mismatch & $0 \%$ & $17.1 \%$ \\
\hline
\end{tabular}

Only at FBN lecture theatre was a non-zero score (5.5\%) returned for seat height - seat depth match. In other words, $5.5 \%$ of the participants in the FBN lecture theatre group found the seat height and seat depth fit for their anthropometric measurements.

\section{DISCUSSION}

The present study provides evidence of a substantial level of mismatch between the anthropometric measures of University undergraduates and the classroom furniture available to them. One reason that may be adduced for the level of match/mismatch between students' anthropometric measures and classroom furniture dimensions is that local artisans have continued to use furniture dimensions that fit anthropometric features of the years back, without considering the change in size of present day students. Secondly, in cases of imported classrooms furniture, the manufacturers give little or no consideration to the anthropometric measures of the local population for whom the furniture is made.

The implication of the mismatch that has been discovered is that many students are either sitting on seats that are too high for them and/or using desks that are too high from the sitting surface. The biomechanical consequences of these are widely reported in literature. According to Parcells et al. [1], when seating surfaces are too high, it causes discomfort and impaired blood circulation around the thighs. The user often has to move forward on the seat as a compensatory measure, thus, assuming a kyphotic posture due to lack of back support. When a seat is too low, the weight of the user is transferred to a small area of the ischial tuberosities resulting in an uneven distribution of pressure over the posterior thigh.

Seats that are too deep for a user usually result in reduced blood flow to the legs and feet because the front edge of the seat presses against the back of the knee. If the user moves forward on the seat as a compensatory measure, a kyphotic posture usually results. When seat depth is too shallow, there is a lack of support for the lower part of the thighs [15]. Furniture with ill-fitted seat-desk clearance also presents a problem. When the knee height is higher than the seat-desk clearance, there is a risk of hitting the knee cap against the desk. Usually, the user will lean forward to use the desk, again resulting in a kyphotic posture. A similar postural position is adopted when the elbow height is higher than the desk height. With desk heights that are higher than the elbow rest height, the user ends up raising the shoulders to use the desk. This puts excess pressure on the shoulders and result in pain and discomfort.

When compared with similar studies conducted in Nigeria $[13,17]$, the result of the present study is similar to those from the previous studies. One may infer that there exists a high level of mismatch between anthropometric measures of students in Nigerian Universities and the dimensions of furniture available to these students. In fact, Ismaila, Musa, Adejuyigbe and Akinyemi [17], reported that as much as $93.75 \%$ of the students complained of neck, shoulder, upper and lower back pains which were all attributable to the furniture they used. Verbal communications with the participants in this present study also revealed that most of them feel a noticeable amount of pain and discomfort.

The use of poorly designed classroom furniture will require greater muscular force and control to maintain stability and equilibrium [1], and often results in discomfort (in the form of irritation) as well as pain on the back and neck and even an alteration in the normal posture of the individual. On the other hand, maintaining an upright sitting posture is beneficial to the back muscles [22] just as much as well-fitting classroom furniture will improve classroom comfort and facilitate learning $[4,22]$.

\section{CONCLUSION}

This study aimed to determine the ergonomic suitability of classroom furniture at the Federal University of Technology, Akure, Nigeria. The result of the study shows that the design and dimension combination of the furniture at the selected lecture venues in FUTA is ergonomically unsuitable for the sample population studied. The findings of the study suggest that there is an important need for the inclusion of anthropometric considerations in classroom furniture manufacturing.

\section{RECOMMENDATIONS}

Since it is evident that furniture manufacturers do not rely on any research for their furniture designs and 
therefore adopt a one-size-fits-all approach [1], policy makers in the education sector should consider regulating school furniture manufacturing to ensure that such furniture do not predispose users to musculoskeletal disorders. In addition, more research on the subject of anthropometry and ergonomic furniture designs is suggested to give furniture manufacturers a pool of data for their designs.

Conflict of Interest: The authors declare that they have no competing interests.

Funding: This research did not receive any specific grant from funding agencies in the public, commercial, or not-for-profit sectors.

\section{REFERENCES}

[1] Parcells, C. Stommel, M. Hubbard, R. P. "Mismatch of classroom furniture and student body dimensions: empirical findings and health implications", Journal of Adolescent Health. Vol. 24, pp. 265-273, 1999.

[2] Cranz, G. "The Alexander technique in the world of design: posture and common chair", Journal of Bodywork Movement Therapy, Vol. 4, Number 2, pp. 90-98, 2000.

[3] Ogunwolu, L. Popoola, O. P. Sosimi, A. A. Raheem, W. A. "An Ergonomic Critique and redesign of a Local Cane Chair in Nigeria with User Body Mass Index", AJERD, Vol. 1, Issue 2, pp.238 - 253, 2018.

[4] Eckelman, C. Haviarova, E. Zui, H, Gibson, H. "Considerations in the design and development of school furniture for developing regions based on local resources", Forest Product Journal. Vol. 51, Number 6, pp. 56-63, 2001.

[5] Corlett, E. N. "Background to sitting at work: research-based requirements for the design of work seats", Ergonomics, Vol. 49. Pp. 1538-1546, 2006.

[6] Murphy, S. Buckle, P. Stubbs, D. “A cross-sectional study of self-reported back and neck pain among English schoolchildren and associated physical and psychological risk factors", Applied Ergonomics, Vol. 38, Number 6, pp. 797-804, 2007.

[7] García-Acosta, G. and Lange-Morales, K. "Definition of sizes for the design of school furniture for Bogotá schools based on anthropometric criteria", Ergonomics, Vol. 50, Number 10, pp. 1626-1642, 2007.

[8] Savanur, C. S. Altekar, C. R. De, A. "Lack of conformity between Indian classroom furniture and student dimensions: proposed future seat/table dimensions", Ergonomics, Vol. 50, pp. 1612-1625, 2007.

[9] Agha S.R. "School furniture match to students' anthropometry in the Gaza strip", Ergonomics, Vol. 53, Number 3, pp. 344-354, 2010.

[10] Castellucci, H. I. Arezes, P. M. Viviani C. "Mismatch between classroom furniture and anthropometric measures in Chilean schools", Applied Ergonomics, Vol. 41, pp. 563-568, 2010.

[11] Castellucci, H. I. Arezes, P. M. Molenbroek J. F. M. "Applying different equations to evaluate the level of mismatch between students and school furniture", Appl. Ergon., Vol. 45, pp. 1123-1132, 2014.

[12] Mokdad, M. and Al-Ansari, M. "Anthropometrics for the design of Bahraini school furniture", International Journal of Industrial Ergonomics, Vol. 39, pp. 728-735, 2009.

[13] Odunaiya, N. A. Owonuwa, D. D. Oguntibeju, 0. 0 "Ergonomic suitability of educational furniture and possible health implication in a University setting", Advances in Medical Education Practice, Vol. 5, pp. $1-14,2014$

[14] Gierlach, P. "Physician perspectives on children musculoskeletal and vision disorders in Geneva, Switzerland", Proceedings of the XVI annual international occupational ergonomics and safety conference, Toronto, Canada, 9-12 June, pp. 1-4, 2002.

[15] Milanese S. and Grimmer K. "School furniture and the user population: an anthropometric perspective" Ergonomics, Vol. 47, Number 4, pp. 416-426. 2004

[16] Osquei-Zadeh, R. Ghamari, J. Abedi, M. and Shiri, H. "Ergonomic and anthropometric consideration for library furniture in an Iranian public University", International Journal of Occupational and Environmental Medicine, Vol. 3, Number 1, 19-26, 2012.

[17] Ismaila, S. O. Musa, A. I. Adejuyigbe, S. B. Akinyemi, O. D. "Anthropometric design of Furniture for use in tertiary institutions in Abeokuta, south western Nigeria", Engineering Review, Vol. 33, Number 3, pp. 179-192, 2013.

[18] Panagiotopoulou, G. Christoulas, K. Papanckolaou, A. Mandroukas, K. "Classroom furniture dimensions and anthropometric measures in primary school", Appl. Ergon., Vol. 35, Number 2, pp. 121-128, 2004.

[19] Taifa, I. W. and Desai, D. A. "Anthropometric measurements for ergonomic design of students' furniture in India", Engineering Science and Technology, an International Journal, Vol. 20, pp. 232-239, 2017.

[20] Pheasant, S. Bodyspace: Anthropometry, Ergonomics and the design of work (2nd Ed.), Taylor and Francis Publishers, London, pp 75-82, 2003.

[21] Gouvali, M. K. and Boudolos, K. "Match between school furniture dimensions and children's anthropometry", Appl. Ergon., Vol. 37, 2006, 765773,2006

[22] Chung, J. W. Y. and Wong T. K. S. "Anthropometric evaluation for primary school furniture design", Ergonomics, Vol. 50, Number 3, 323-334, 2007. 